University of Pennsylvania Carey Law School

Penn Law: Legal Scholarship Repository

Faculty Scholarship at Penn Law

$1-11-2012$

\title{
Rewards for Rights Ratification? Testing for Tangible and Intangible Benefits of Human Rights Treaty Ratification
}

Richard Neilsen

Massachusetts Institute of Technology

Beth A. Simmons

University of Pennsylvania Carey Law School

Follow this and additional works at: https://scholarship.law.upenn.edu/faculty_scholarship

Part of the International Humanitarian Law Commons, International Law Commons, International Relations Commons, Law and Politics Commons, Other International and Area Studies Commons, Policy History, Theory, and Methods Commons, Public Affairs Commons, Public Law and Legal Theory Commons, and the Public Policy Commons

\section{Repository Citation}

Neilsen, Richard and Simmons, Beth A., "Rewards for Rights Ratification? Testing for Tangible and Intangible Benefits of Human Rights Treaty Ratification" (2012). Faculty Scholarship at Penn Law. 1687. https://scholarship.law.upenn.edu/faculty_scholarship/1687

This Article is brought to you for free and open access by Penn Law: Legal Scholarship Repository. It has been accepted for inclusion in Faculty Scholarship at Penn Law by an authorized administrator of Penn Law: Legal Scholarship Repository. For more information, please contact PennlawIR@law.upenn.edu. 


\title{
Rewards for Rights Ratification?
}

\section{Testing for Tangible and Intangible Benefits of Human Rights Treaty Ratification}

\author{
Richard Nielsen \\ PhD Candidate, Government Department \\ Harvard University \\ nielsen.rich@gmail.com \\ Beth A. Simmons \\ Clarence Dillon Professor of International Affairs \\ Government Department, Harvard University \\ bsimmons@wcfia.harvard.edu
}

Draft date: 11 January 2012

\begin{abstract}
We appreciate financial support for research assistance from the Institute for Quantitative Social Science at Harvard University. John Sheffield provided excellent research assistance. We appreciate helpful comments from Resat Bayer, Tanya Boerzel, Allison Brysk, Andy Eggers, Andreas Føllesdal, Ryan Goodman, Darren Hawkins, Iain Johnston, Thomas Risse, Anne Julie Semb, Geir Ulfstein, Jane Vaynman, and Erik Voeten. Beth Simmons wishes to acknowledge that her work on this article was written as part of the international research program on 'Should States Ratify Human Rights Conventions?' at the Centre for Advanced Study at the Norwegian Academy of Science and Letters in Oslo during the academic year 2009/2010. Rich Nielsen acknowledges support from a National Science Foundation Graduate Research Fellowship.
\end{abstract}




\begin{abstract}
Among the explanations for state ratification of human rights treaties, few are more common and widely accepted than the conjecture that states are rewarded for ratification by other states. These rewards are expected to come in the form of tangible benefits - foreign aid, trade, and investment - and intangible benefits such as praise, acceptance, and legitimacy. Surprisingly, these explanations for ratification have never been tested empirically. We summarize and clarify the theoretical underpinnings of "reward-for-ratification" theories and test these propositions empirically by looking for increased international financial flows and public praise and recognition following ratification of four prominent human rights treaties. We find almost no evidence that states can expect increased tangible or intangible rewards after ratification. Given the lack of empirical support, explanations rooted in domestic politics seem a more appealing alternative for understanding human rights treaty ratification.
\end{abstract}

Word Count: 9,185 
Few trends in international law and international relations are as curious as the well-documented trend for independent states to agree to allow the international community to pass judgment on their internal human rights practices. More than 45 human rights treaties concluded since the Second World War now recognize in effect the legitimacy of external actors' concerns about domestic rights practices (Simmons 2009). The "accountability revolution" in human rights has been noted by a number of authors to be one of the most significant trends in international law and international affairs in the past halfcentury (Clark 2001; Ignatieff 2001).

From traditional theoretical perspectives, state accession to the "rights revolution" is indeed puzzling. Why should sovereign states agree to make an internal issue subject to international standards and external review? How can we understand the apparently voluntary decision to ratify international human rights agreements that create legal obligations to protect and provide for the human rights of one's nationals? Scholars have proposed three kinds of answers. The first downplays the significance of the international human rights regime as meaningless because it is largely unenforceable (Krasner 1999; Krasner and Frotas 1998). A second approach acknowledges that international treaty commitments are potentially costly because they may create pressures for adjustments in policies and practices. These scholars often attribute ratification to the desire to attract some kind of material payoff: because these agreements compromise sovereignty, there must be some kind of reward as a matter of implicit or even explicit quid pro quo. A final approach is to attribute ratification to intangible benefits. Belonging, praise, acceptance, respect, inclusion - these signs of social approval are at the heart of the ratification decision for ideational theorists working in a more sociological vein. Governments ratify human rights agreements, in this view, not because they are remunerative in a material sense, but because ratification ushers a state into the circles of the most respected countries in the world.

Surprisingly, none of these explanations has undergone serious empirical scrutiny. To do so is the main purpose of this study. We ask, does ratification actually lead to the consequences said to motivate the behavior in the first place? At first blush it may seem as though we are explaining a decision by its outcome, but this is an entirely legitimate approach in this case. If states did not anticipate positive 
consequences, as these theories suggest, they would have little motivation to ratify. Their anticipation must be correct on average, or else most governments would update their expectations about the advantages that ratification brings. If we observe payoffs (tangible or intangible) to ratification, there is a strong prima facie case for a reward-based ratification motive. But if no such relationship can be found, we may have to look elsewhere for a theory of commitment to international human rights standards.

This article proceeds as follows. In the first section, we review the prevalent theoretical approaches to analyzing the puzzle of human rights treaty ratification. The second section discusses what we should expect to observe empirically if "quid-pro-quo" theories of ratification are useful. The third section discusses the data and methods, and the fourth section presents the results. In the conclusion, we suggest alternative ways to think about the ratification decision. We argue that it is likely that most countries ratify treaties not for what they expect to gain from outsiders, but for domestic political purposes. Strategic ratification certainly can happen, but it rarely yields the rewards some people seem to assume.

\section{Human Rights and International Relations: The Ratification Puzzle}

There are many ways to think about the influences on governments' commitments to international human rights treaties. One is to think of a treaty commitment as a low-cost opportunity to express support for a cooperative international endeavor. Hathaway has proposed that governments ratify treaties because they allow a costless expression of support for the principles they contain. Those who ratify reap "expressive" benefits, that is, "rewards for positions rather than for effects"” (Hathaway 2002). Because human rights agreements are not effectively monitored, "the expressive benefits that countries gain from the act of joining the treaty will be enjoyed... regardless of whether they actually comply with the treaty's requirements" (Hathaway 2002). In this view, international legal arrangements are weak, enforcement is unlikely, and costs of non-compliance are low. Why not ratify, and gain some support or at least praise from the international community for doing so? The act of ratification, in this view, is driven by the 
potential benefits of signing an agreement that goes unmonitored. Two kinds of benefits are often asserted to be available: tangible economic benefits and intangible social "legitimation." Together, we refer to these types of approaches as rewards theory.

\section{Tangible rewards}

In some accounts, the benefits governments expect when they commit themselves to international human rights standards are blatantly mercenary. Hathaway is clear about the tangible nature of the quidpro-quo:

Simply put, states join treaties like the Convention against Torture [CAT] in no small part to make themselves look good. In so doing, they may hope to attract more foreign investment, aid donations, international trade, and other tangible benefits (Hathaway 2004).

Economic benefits are among the "collateral [non-legal] consequences" of human rights treaty ratification, according to Hathaway (2007).

Similar propositions abound in the literature. Hawkins and Goodliffe explain ratification of the CAT by arguing that "other states and third party actors (corporations and NGOs) reward that state through investment, trade, aid and positive political relationships" (Hawkins and Goodliffe 2006). Boockman asserts that international aid could influence the decision to ratify International Labor Organization (ILO) conventions (Boockmann 2001). Posner $(2008,1769)$ lists "pressure from western states that tied aid and other benefits (such as EU membership) to treaty ratification" as the first reason developing states ratify human rights treaties. And Trachtman (forthcoming 2012) finds other explanations for treaty ratification "less plausible" than a quid pro quo logic of rewards. Moreover, despite recognition that the multilateral aid organizations such as the World Bank do not explicitly link their assistance to human rights treaty ratification, the idea persists in the literature that "International organizations also encourage ratification by linking a treaty with material goals, such as economic aid" (Oberdörster 2008). 
The idea that human rights policies are enforced by the manipulation of rewards and punishments is hardly universally accepted. Realists assert that governments are not generally willing to expend significant resources on foreign human rights practices at all. (Goldsmith and Posner 2000). But even if states were inclined to enforce foreign citizens' rights, why would treaty ratification be a credible signal of states' intentions to comply with international norms of human rights protections? It is not uncommon for international legal theorists to assert the critical role of treaty ratification as an expression of a serious intent on the part of states to behave as the ratified treaty requires. Guzman, for example, argues (though not specifically in the context of human rights) that treaties involve "the complete pledge of a nation's reputational capital" (Guzman 2002) and as such can sometimes constitute a credible commitment on the part of states to comply with their provisions. But in the absence of reciprocity - notably lacking in the human rights area - there is no clear reason for such an essentially unenforceable pledge to put much at stake. The puzzle deepens if we buy the common observation that treaties do little to persuade the worst right offenders to improve their policies (Hafner-Burton and Tsutsui 2007; Hollyer and Rosendorff 2011).

Perhaps the answer to the credibility conundrum - why should government or economic agents be impressed with treaty ratification? - lies in the type of agreements that states choose to ratify. Smith argues that during especially hard economic times, states consciously join enforceable human rights agreements, such as the Optional Protocol to the International Covenant on Civil and Political Rights (ICCPR), which gives individuals the right to complain of a treaty violation to the Human Rights Committee, or the making of an Article 22 Declaration regarding the CAT, which provides individuals similar standing before the Committee Against Torture (Smith forthcoming). She argues that ratification of enforceable agreements is an opportunity for states to collect aid from donors that may care about human rights. Such a commitment could also (in theory) convince private investors and traders that the ratifying government has long time horizons, and that the government may forego opportunistic policies such as "takings" that degrade the value of an investment. While this approach addresses the theoretical puzzle of how states might be able to signal their credibility, it again relies on the untested assumption 
that other states and non-state actors will in fact reward "costly" treaty commitments with various forms of economic largesse.

To clarify, we do not doubt that some countries and organizations use economic leverage to encourage states to improve their human rights behavior and to encourage the consolidation of democratic institutions. The European Union and NATO may sometimes employ various forms of conditionality in this way (Hawkins 2004; Kelley 2004; Sanahuja 2000). However, careful studies of the use of the European Union's “conditionality clause" reveal not one instance of invocation due to refusal to ratify a human rights treaty (Moberg 2009). Furthermore, while there may be very good theoretical reasons to expect that the actual protection of rights in domestic law and practice does constitute a costly signal of governments' intentions (Farber 2002), we are skeptical that states and commercial interests reward ratification per se. Aid donors typically monitor their recipients and have been known to change their giving to reward not ratification, but actual policy changes (Alston and Crawford 2000; Nielsen 2008). For example, in 1975, the US Congress passed legislation prohibiting the extension of foreign economic assistance to countries with severe human rights violations. But rather than relying on the "signal" sent by treaty ratification, Congress commissioned detailed human rights reports for each potential aid recipient, suggesting that donors find it worth their while to collect information on actual human rights practices when they make their aid decisions.

In short, the current literature largely assumes - on wobbly theoretical grounds and without empirical support - that governments ratify human rights agreements because they expect some kind of material rewards, whether official aid, liberalized trade, or private investment. Practically nothing is said about when such rewards are doled out: As an inducement or capacity-building effort prior to ratification, as the "management school" of compliance might suggest (Chayes and Chayes 1993)? As a post hoc reward for having ratified a key treaty? Rewards theorists are even less definitive about who is responsible for making decisions about tangible rewards; indeed, there is practically no attention given to the varying motives of governments versus principled NGOs versus profit-seeking private actors. Still, the tangible rewards assumption is so pervasive that it merits close empirical scrutiny, if for no other 
reason than to encourage social scientists to develop better explanations for the legalization of human rights over the past five decades.

\section{Intangible Rewards}

A second set of explanations for human rights treaty ratification stresses the importance governments attach to the approval of the international community as a motivation to ratify human rights agreements. Less crass than a ratification-for-cash model, ratification is widely seen especially by sociologists and political scientists working in a constructivist vein as an expression of the desire to "belong" as a "member in good standing" to the international community of "modern" nations.

Sociological theories tend to emphasize the collective legitimating function of international legal agreements, especially in the human rights area. "International law and international organizations are still the primary vehicles for stating community norms and for collective legitimation," according to a classic study on international human rights norms (Risse and Sikkink 1999). Governments have been "socialized" to care about what other states think of them, which might explain variance in ratification across countries and regions of the world (Lutz and Sikkink 2000). International law plays a central role in this theory of state action. Landman (2005) refers to the ratification of human rights treaties as a "socially embedded unit act" implying that the act has meaning largely because of the value assigned to it by the international community of nations. The value the international community places on these agreements generates subtle pressures to ratify.

Some scholars believe that participating in the social act of treaty ratification imparts a degree of legitimacy to the government and/or the state taking that action. Hafner-Burton and Tsutsui for example note the "strong pressures to ratify international human rights treaties" and assert that "ratification puts a legitimate face on the government..." (Hafner-Burton and Tsutsui 2005). This need for legitimacy, coupled with awareness that commitment to the regime is seldom costly in practice, is said to produce radical decoupling between policy decisions to ratify and actual human rights behaviors. Landman 
(2005) similarly refers to the need of new "fourth wave" democracies to garner international legitimacy, and cites this need as a reason for human rights treaty ratification.

Closely related to the social meaning of human rights treaty ratification is the desire of states to avoid criticism. Avoidance of criticism is not merely instrumental; ideational theories emphasize that it is coupled with state self-perceptions of identity. Hawkins explains states' shifting positions on the universal jurisdiction provisions of the CAT as a reflection of efforts to "avoid positions in which they would stand alone against other states, especially those with similar identities" (Hawkins 2004, 793). Hawkins' interview with Hans Danelius, a Swedish foreign ministry official who was intimately involved in the negotiations reveals that concern about shaming was a primary motivation for the growing homogeneity of opinion in support of universal jurisdiction. Simmons suggests that the desire to avoid criticism may motivate some "insincere" states to ratify human rights agreements, but that this is a strategy that makes sense only in the short run and only when relatively little information is available on actual practices (Simmons 2009). States sometimes also respond to naming and shaming by attempting to neutralize its effectiveness. Engleheart (Engleheart 2003, 44) identifies the 1993 Bangkok Declaration as an exercise of international solidarity representing a "serious attempt to shift international human rights norms, in order to weaken the strategy of shaming." From a constructivist perspective, shaming can represent a real cost to states that seek acceptance by international society, with praise representing the opposite side of the same coin.

Seeking to understand how human rights norms and identities spread internationally, sociologists have applied the concept of "World Culture" to capture the idea that values, norms, and ideas of what constitutes proper behavior of a modern state diffuse in varying degrees globally. One way to interpret patterns of treaty ratification is to situate states in a global macrosociological context, and view ratification as one instantiation of a diffusing logic of appropriateness that encourages governments to want to present themselves to the broader international community and to their own citizens as actors that affirm the basic rights of individuals. Ratification in this context can be thought of as an act of emulation, in which states "enact" the values of a broader western progressive culture, in an effort formally to 
identify themselves as members in "good standing" of the modern society of states (Meyer et al. 1997). In the case of human rights treaty ratification these standards of good standing are transmitted via international conferences, organizations, and the signals sent by the ratifications of peers (Berkovitch 1999; Boli and Thomas 1999). Treaty ratification is one way to enact the "script" of modernity in this view (Wotipka and Ramirez 2008), rendered more likely when the nation-state is embedded in the structures of international society. But to the extent that ratification is mere enactment of these external scripts of modernity, it represents nothing more than "isomorphism" - or the adoption of superficially similar formal policies without their internalization.

While these various ideational mechanisms are very different - shaming and persuasion imply active policies on the part of pro-rights agents, while theories that point to the mere availability of modern scripts view core states as more passive - all suggest there are intangible external pressures for treaty ratification. And yet the logic of ratifying in order to glean external social approval is questionable. Social approval might be a plausible explanation for ratification if no one cares to follow up, but this explanation seems a poor fit for a world in which citizens, other governments, and assorted transnational advocacy groups value actual practices over mere ratification and have reasonably good information on the former. There seems to be an obvious internal contradiction in the claim that "Repressive states want the legitimacy that the human rights treaties confer on them more than non-repressive states because they are under tighter scrutiny for their practices" (Hafner-Burton, Tsutsui, and Meyer 2008). It is far from clear how treaty ratification alone grants "legitimacy" if observers are scrutinizing state behavior (Goodman and Jinks 2003).

\section{Rewards theory and the empirical puzzle of ratification}

Rewards theory suffers on logical grounds, but has a hard time explaining empirical realities as well. If treaty ratification is universally costless (or even profitable?), then ratification of human rights accords should have been immediate and universal. Instead, it took ten years for the requisite thirty-five countries to ratify the ICCPR to bring it into force, and thirty-five years later, accession is still not 
universal. The CAT has gleaned relatively few state parties: only slightly over half of the countries in the world ratified in the first twenty years it was open for ratification. With the possible exception of the Convention on the Rights of the Child (which has weak enforcement provisions and many aspirational obligations), not all governments have been in a rush to express even symbolic support for the six core human rights treaties. ${ }^{1}$

Of course these ratification patterns are only circumstantial evidence that rewards rarely motivate ratification of international human rights treaties. In the sections that follow, we ask whether rewards are actually forthcoming when ratification takes place. If not, we believe it is time to search for new explanations for why governments have committed themselves voluntarily to international legal commitments to respect the rights of their own people.

\section{Hypotheses: Testing the Claims of Rewards for Ratification}

Rewards theory posits that human rights treaty ratification is done in response to or in anticipation of external incentives, both tangible and intangible, leading us to test the following hypotheses.

Bilateral foreign aid - the most easily manipulable form of reward for ratification - should increase with ratification or slightly prior, if it is being offered by foreign governments as an inducement to ratify. We would expect the strongest increases from governments that place the highest premium on treaty ratification: governments which themselves have already ratified.

Trade and investment are not as easy for market-oriented governments to manipulate in response to treaty ratification. To our knowledge, lack of international human rights treaty ratification has never been the primary motive for a sanctioning episode. We therefore expect that the rewards to ratification do not primarily flow from government policies, but rather from the decisions of private actors when they see a government ratify an agreement. The likely mechanism in this case is the signaling function that

\footnotetext{
${ }^{1}$ For a detailed look at the Kaplan-Meier survival functions for ratification of each treaty, see [author's website]
} 
ratification may entail: ratification signals to private agents that the government has a reasonably long time horizon and is likely to treat foreign economic investments - like its own people - with reasonable respect (Farber 2002). If this is the case, we are not very likely to see anticipatory economic investments; indeed, there could be quite a delay between ratification and a noticeable upswing in foreign economic "rewards." A plausible hypothesis therefore is that ratification is followed by increased foreign investment and trade flows in the medium term; for example, within one to three years. Note also that if ratification sends a credible signal about time horizons to economic agents, the national source of trade or investment should not matter. In principle, economic agents from any part of the world can see and interpret ratification as indicative of a government willing to forego opportunistic gains in the short run for longer term payoffs.

Our second (and more challenging) empirical task is to test the claim that governments ratify human rights treaties for the intangible rewards - external acceptance or approval and the sense of legitimacy or belonging that it may impart to the ratifying nation. Essentially, this is a claim about something utterly unobservable: the psychological boost a set of policymakers experience when they feel they have done something that meets with the approval of external actors whose approval they value. This kind of reward is internally experienced, and we cannot in this paper directly evaluate the claim made by world society theorists that enacting modernity offers such psychic rewards. But we can at least provide a systematic empirical test of the proposition that governments ratify human rights agreements in order to gain external approval or praise - outcomes we would understand as constituting "expressive benefits" in Hathaway's words, or "social coercion" in Goodman and Jinks' formulation.

If external approval is an important motivation, then it should be possible to connect ratification with some form of public praise from important global actors: for example, the European Union, the United States, and the most visible non-state human rights organization, Amnesty International. Public references to the government's ratification should be more likely and more positive if the external actor itself has ratified the treaty in question. Finally, public references should be more likely and more 
positive when the treaty in question constitutes a credible commitment; that is, when it is non-derogable and to some degree enforceable.

\section{Data and Methods}

\section{Measuring Treaty Ratification}

Although the rewards-for-ratification argument is often loosely applied to all human rights treaties, we focus on the easiest cases for the theory: The International Covenant on Civil and Political Rights (ICCPR) $)^{2}$, the First Optional Protocol to the International Covenant on Civil and Political Rights $(\mathrm{OP} 1)^{3}$, The Convention Against Torture (CAT) ${ }^{4}$, and the optional $22^{\text {nd }}$ Article of the Convention Against Torture (Art. 22). The two treaties and two optional obligations we have chosen are four of the most significant international human rights agreements in existence and form the core of the voluntary multilateral legal apparatus protecting personal integrity, civil, and political rights. If rewards do not follow ratification of these key treaties, it is doubtful that there are rewards for ratifying other human rights agreements such as the largely hortatory Convention on the Rights of the Child or the new Disabilities Convention. Additionally, the treaties we examine display variance on the credibility of commitments. Ratifying the ICCPR and CAT may be cheap talk but the ICCPR Optional Protocol 1 and CAT Article 22 tie a state to external oversight of particular cases by allowing individuals from ratifying states to report human rights abuses directly to the respective treaty oversight committee. Presumably, this creates a higher probability that violations will be noticed, condemned or possibly sanctioned.

We consider each time that a state ratifies any one of these four treaties to be a ratification episode. Rewards theory is vague about the timing of rewards, so we look for rewards in the year of, and up to five years after ratification. We compare these ratification episodes to identically sized historical periods from countries that have not (yet) ratified a particular human rights treaty. For example, Bolivia

\footnotetext{
${ }^{2}$ Text of the ICCPR can be found at: http://www2.ohchr.org/english/law/ccpr.htm (Accessed 16 December 2011).

${ }^{3}$ Text of the ICCPR's First Optional Protocol can be found at: http://www2.ohchr.org/english/law/ccpr-one.htm (Accessed 16 December 2011).

${ }^{4}$ Text of the CAT can be found at: http://www2.ohchr.org/english/law/cat.htm. (Accessed 16 December 2011).
} 
did not ratify the CAT between 1985 and 1995, making Bolivia-1990 (the focal year is 1990) an episode of non-ratification that we can compare to episodes of ratification. Non-ratification episodes may overlap - Bolivia also did not ratify the CAT between 1986 and 1996 which we consider to be another ratification episode. We account for the non-independence of these overlapping non-ratification episodes in our statistical models by using country-level random effects and clustered errors. Ratification episodes may come from the earlier history of countries that eventually ratify a treaty - Bolivia eventually ratified the CAT in 1998 - but we do not allow ratification episodes and non-ratification episodes to overlap.

Episodes of treaty ratification are likely to be different from many of the episodes of nonratification, presenting potential problems of selection bias. For example, we find that in the five years prior to ratification of the CAT, states had higher GDP, trade flows, and political freedoms, and lower aid flows, relative to states that did not subsequently ratify. If these differences are also associated with the hypothesized rewards, then direct comparison of ratification and non-ratification episodes will lead to biased estimates of the effect of ratification unless we make adjustments for these differences. We address this problem by first pre-processing the data using matching (Ho et al. 2007), which results in a matched sample in which the ratification- and non-ratification episodes are comparable. ${ }^{5}$ We then use standard regression techniques to compare similar ratification and non-ratification episodes, controlling for the observed differences in the relevant control variables in each of the five year periods prior to ratification (or non-ratification, in the case of non-ratification episodes). ${ }^{6}$ Because we have repeated episodes of non-ratification from the same countries, we use a hierarchical model with country-level random effects and clustered standard errors to account for unobserved similarities that are constant within countries across time. Throughout, we control for actual human rights practices to test the

\footnotetext{
${ }^{5}$ Our specific matching procedure uses the Mahalanobis distance metric defined using the pre-ratification covariates such that units that are close together have similar values of these covariates (Rubin 1980). We define a caliper - the maximum allowable Mahalanobis distance between matched episodes of ratification and nonratification. Then, for each ratification episode, we retain all of the non-ratification episodes that fall within this caliper. Non-ratification episodes that are not close enough to any of the ratification episodes are discarded to avoid the potentially serious model dependence that would result from including these very dissimilar units.

${ }^{6}$ The results are similar when we use regression without matching. We believe the matching results to be more credible because they rely less on un-testable modeling assumptions see for example
} 
proposition that ratification alone elicits rewards from the international community. Data on violations of physical integrity rights come from Cingranelli and Richards (2008).

If treaty ratification is a significant predictor of increased rewards in the five years following ratification, using the standard 95 percent cut-off in a two-tailed test, we conclude that the hypothesis is supported. Well-known statistical results on multiple testing imply that our actual level of statistical confidence across multiple models will be lower than 95 percent; but as we will see, we are generally unable to reject the null hypothesis that there are no rewards for ratification, even at this lower level of implied confidence.

\section{Measuring Tangible Rewards}

Foreign Aid: We measure foreign aid using logged per capita bilateral aid flows from western donors to 120 developing countries between 1981 and 2004 (OECD 2008). Our coefficients can be interpreted as elasticities - percentage changes in the flow of aid in response to ratification and other variables.

We include a number of standard control variables drawn from the literature on aid flows. As measures of recipient need, we use GDP per capita and GDP per capita ${ }^{2}$, as well as Population and Population $^{2}$. Donors' strategic interests are widely found to influence aid flows, so we include Trade and Trade $^{2}$, Formal Alliances and Donor Forces stationed in the recipient, an indicator for whether a recipient is a former Colony of an aid donor, an indicator for Socialist states, an indicator for years of the Cold War, as well as the multiplicative interaction of Socialist ${ }^{*}$ Cold War, whether a recipient is involved in an interstate or civil War, and indicator variables for the US-Egypt and US-Israel dyads to account for the special aid relationships there. Foreign aid flows may be influenced by bureaucratic inertia (Carey 2007), and so we include Aid receipts (t-1) and the total amount of aid given worldwide by each donor.

Trade: To estimate trade rewards, we turn to a dyadic dataset of import flows and use a modification of the well-known gravity model (see Goldstein, Rivers, and Tomz 2007), adding treaty ratification as an independent variable. We measure trade as the natural log of imports from the first 
country in each directed dyad to the second country. Control variables include WTO participation (an indicator for dyads with Both formal GATT/WTO members, and a separate indicator for dyads with Only one formal GATT/WTO member), other types of trade agreements, including Reciprocal and Nonreciprocal PTAs, an indicator for dyads where trade is subject to the Generalized System of Preferences (GSP), dyads that have a Currency Union, and dyads that are in the same Colonial Orbit. Finally, we include a variety of cultural and geographic control variables: Distance, an indicator for countries that have a Shared Border, counts of the number of Landlocked or Island states in each dyad, an indicator of Common Language between dyad pairs, and the natural log of the product of the Land Areas between paired countries.

Foreign Direct Investment: We test for investment rewards using a dataset of (logged) FDI inflows between 1980 and 2000. Taking standard controls from the FDI literature (Blanton and Blanton 2007; Li and Resnick 2003), we include measures of market size and potential for market growth, namely Trade, GDP per capita, GDP per capita ${ }^{2}$ and GDP growth. We also include measures of financial stability such as Exchange Rate Volatility averaged over 1980-2000 and Inflation measured using the GDP deflator for each country and year. Because political openness and stability may matter for foreign investors (Jensen 2003; Li and Resnick 2003), we control for Democracy and Regime Durability (defined as the length of time since a major change in the democracy scores).

\section{Measuring Intangible Rewards}

We measure incidents of praise and criticism using data from newly collected and previously existing text resources representing the views of the European Union, the United States, and Amnesty International. We collected 34,335 European Union press releases - more than three a day on average published between 1985 and 2010 on the full range of political topics engaged by the European Union. If praise occurs, we expect it to be evident in these press releases, since the European Union has led the way in the international human rights regime, has significant economic and political might, and (arguably) forms the core of the international community of law-abiding states. 
Because praise is more immediate and short-lived than flows of aid or trade, we keep the ratification episode framework introduced above, but shorten the period to include the 365 days prior to and the 365 following the exact ratification date. To measure praise in EU press releases, we first identify each episode of ratification and then examine (1) the existence of explicit praise, (2) positive versus negative language and (3) reference to official state visits.

Although the EU is the most likely source of intangible positive reinforcement, we also consider the possibility that states could be ratifying to seek praise from the United States. We obtained the US State Department Daily Press Briefings between January 2, 1991 and December 23, 2008, for a total of 3,625 briefings. These cover US responses to recent international events, US policy in relation to foreign countries, and US actions abroad. ${ }^{7}$ We analyze these briefings in the same ways as the EU press releases: first searching for explicit praise for ratification, and then attempting to identify shifts in the tone of speech surrounding references to ratifying countries as well as evidence of increases in official visits with recent ratifiers.

Finally, we use data on criticism by Amnesty International collected by Ron et al (2005) to test whether ratification of human rights treaties mutes criticism by non-state actors. Rather than using the full text of Amnesty International's reports, we estimate models predicting the number of critical reports about a particular country released in a given year, using a set of variables collected and used by Ron et al. To these variables we add variables coding whether each country ratified a human rights agreement in the current year to see whether this predicts lower criticism by Amnesty.

\section{Findings}

\section{Tangible Rewards}

Overall, our findings offer virtually no support for the hypothesis that tangible rewards accrue to states that ratify human rights treaties. In Table 1, we report the coefficients on the key variable of

\footnotetext{
${ }^{7}$ http://www.state.gov/r/pa/prs/dpb/. (Accessed 10 January 2012.)
} 
interest: ratification of the four key human rights treaties. Our focus is on causal estimates of the effect of treaty ratification, so other coefficients are omitted from the table. This brevity is not a loss - the other coefficients are generally not amenable to causal interpretation, especially after our matching procedure.

\begin{tabular}{|c|c|c|c|c|}
\hline \multirow[t]{2}{*}{ Outcome Variable } & \multicolumn{4}{|c|}{ Foreign Aid } \\
\hline & Model 1 & Model 2 & Model 3 & Model 4 \\
\hline Treaty & ICCPR & OP 1 & CAT & Art. 22 \\
\hline $\begin{array}{l}\text { Effect of Ratification } \\
\text { (Clustered standard error) }\end{array}$ & $\begin{array}{l}13.9 \\
(15.0)\end{array}$ & $\begin{array}{l}-5.4 \\
(8.9)\end{array}$ & $\begin{array}{c}.8 \\
(23.2)\end{array}$ & $\begin{array}{c}.1 \\
(10.8)\end{array}$ \\
\hline $\mathrm{N}$ ratification episodes & 31 & 36 & 30 & 11 \\
\hline $\mathrm{N}$ non-ratification episodes & 280 & 675 & 291 & 541 \\
\hline R-squared & 0.82 & 0.66 & 0.71 & 0.61 \\
\hline Matching & Yes & Yes & Yes & Yes \\
\hline Controls & \multicolumn{4}{|c|}{$\begin{array}{l}\text { Physical integrity rights, political rights, foreign aid from all donors, } \\
\text { foreign aid from donors that are signatories to the treaty, GDP p.c., GDP } \\
\text { p.c. }{ }^{2} \text {, population, population }{ }^{2} \text {, colonial relationships, alliances with aid } \\
\text { donors, an indicator for the Cold War, and an indicator for ongoing war. } \\
\text { The models include one- through five-year lags of each of the time- } \\
\text { varying variables. }\end{array}$} \\
\hline
\end{tabular}

Table 1: Linear regression of aid flows on treaty ratification with standard errors clustered by country and country random effects. The unit of observation is the (non-)ratification episode, with ratification occurring in year $t$, the covariates measured in the years $t-1, t-2, t-3, t-4$, and $t-5$. The outcome variable is total receipts of foreign aid from donors who have ratified the relevant treaty in years $t$ through $t+5$.

We find that ratification of four human rights treaties has no effect on the average level of aid that countries receive in the year of ratification and the five years following. The estimated gains in aid from ratifying the ICCPR, its Optional Protocol 1, the CAT, and Article 22 are generally small and in all cases statistically indistinguishable from zero. These null results are robust. We were unable to coerce a stronger result by logging the outcome variable, using a Tobit specification, using fewer lags on the control variables, looking at aid from all donors (not just those that have ratified the same agreement), and omitting the matching.

These findings on the weak relationship between ratification and official aid comport with qualitative interview evidence. When asked specifically whether treaty ratification influences aid 
decisions, knowledgeable European decision makers answer unambiguously in the negative. Norwegian officials at the Ministry of Foreign Affairs working at the intersection of human rights and development assistance were quite clear in denying that aid policies had any linkages with a country's status as a party to any human rights treaties. ${ }^{8}$ Development aid was described as being on a "different track," and while they often discussed human rights with officials from recipient states, aid was never conditional on treaty ratification. Similarly, an official from the German Foreign Ministry who headed the Human Rights Department from 2003 to 2008 indicated that while German policy did emphasize human rights, there was no aid conditionality relating to ratification of treaties. He noted that "ratification of hr [human rights] treaties is one thing, the strict (or even not so strict) observance of the respective treaties' provisions is a completely different one..." Furthermore, "coercion and clear pressure - at least with the means at our disposal - generally doesn't have the desired effect in the country at hand but rather satisfies our own public's needs' (including those of NGOs)." "9 For these reasons, Germany urges ratification but does not make a link between ratification and aid. The aid-for-ratification story is neither supported by the statistical evidence, nor does it ring true for practitioners in a position to know.

Turning to trade, we find results that sharply contradict rewards theory: states could be losing trade after ratifying some human rights treaties. Table 2 shows the results of four models predicting the imports to OECD countries from non-OECD countries. Countries that ratify Optional Protocol 1 seem to be losing roughly 24 percent of trade over the next six years relative to similar countries that haven't ratified this optional clause, and this effect is highly statistically significant. ${ }^{10}$ Ratification of the ICCPR, CAT and Article 22 also seem to lead to slight decreases in trade on average, but these estimates are not significantly different from zero. We were unable to coax a positive, significant result out of any of these

\footnotetext{
8 Interviews at the Ministry of Foreign Affairs, Oslo, 6 August 2009. Officials interviewed: Anne Marchant, Ambassador, Human Rights Issues, Section for Human Rights and Democracy, and Geir Løkken, Assistant Director General, Minister of International Development's Policy Analysis Unit. Ministry of Foreign Affairs, Norway. ${ }^{9}$ Interview with Peter Rothen, Head of the German Foreign Office's Human Rights Department 2003-2008; via email correspondence; 11 August 2009.

${ }^{10}$ Recalling that the outcome variable is logged trade, we coefficients are best interpreted as percentage changes in trade as a result of a unit increase (elasticities). For indicator variables like treaty ratification, this calculations is $100 *(\exp (\beta)-1)$, or $100 *(\exp (-.28)-1)=-24$ in this case.
} 
models even after a variety of changes. A number of reasonable alternative specifications even resulted in stronger negative results: most notably when we only use 3 years of lags for the control variables (instead of 5) and/or shorten the rewards period to three years after ratification.

\begin{tabular}{|c|c|c|c|c|}
\hline \multirow[t]{2}{*}{ Outcome Variable } & \multicolumn{4}{|c|}{ Trade Imports between Dyads } \\
\hline & Model 5 & Model 6 & Model 7 & Model 8 \\
\hline Treaty & ICCPR & OP 1 & CAT & Art. 22 \\
\hline $\begin{array}{l}\text { Effect of Ratification } \\
\text { (Clustered standard error) }\end{array}$ & $\begin{array}{l}-.12 \\
(.08)\end{array}$ & $\begin{array}{l}-.28 * \\
(.07)\end{array}$ & $\begin{array}{l}-.025 \\
(.057)\end{array}$ & $\begin{array}{l}-.007 \\
(.13)\end{array}$ \\
\hline $\mathrm{N}$ ratification episodes & 245 & 194 & 458 & 87 \\
\hline $\mathrm{N}$ non-ratification episodes & 264 & 185 & 573 & 235 \\
\hline R-squared & 0.94 & 0.92 & 0.91 & 0.90 \\
\hline Matching & Yes & Yes & Yes & Yes \\
\hline Controls & \multicolumn{4}{|c|}{$\begin{array}{l}\text { Dyadic distance, past dyadic imports, source country physical integrity } \\
\text { rights, source country political rights, GATT membership, preferentia } \\
\text { trade agreements, GSP programs, GDP, land area, and indicators for } \\
\text { shared language, shared borders, landlocked states, and islands. The } \\
\text { models include one- through five-year lags of each of the time-varying } \\
\text { variables. }\end{array}$} \\
\hline
\end{tabular}

Table 2: Linear regression of trade imports from non-OECD countries to OECD countries on treaty ratification with standard errors clustered by country and country random effects. The unit of observation is the (non-)ratification episode dyad, with ratification occurring in year $t$, the covariates measured in the years $t-1, t-2, t-3, t-4$, and $t-5$. The outcome variable is total imports from non-OECD countries to OECD countries that have ratified the relevant treaty in years $t$ through $t+5$. * indicates $\mathrm{p}<0.05$.

As with aid and trade, we find little support for the hypothesis that FDI inflows increase in the wake of human rights treaty ratification. Ratification is a statistically insignificant predictor of FDI flows in all of the models we estimate and this null finding is robust to a variety of possible specifications of FDI including logged inflows (shown in Table 3), inflows over GDP, and raw inflows. Although the estimated effect sizes are large - for example, we find a roughly a 39 percent reduction in FDI inflows attributable to ICCPR ratification in the following six years - they are each estimated extremely imprecisely such that the truth could in fact be a zero effect for each. 


\begin{tabular}{|c|c|c|c|c|}
\hline \multirow[t]{2}{*}{ Outcome Variable } & \multicolumn{4}{|c|}{ Logged FDI inflows } \\
\hline & Model 9 & Model 10 & Model 11 & Model 12 \\
\hline Treaty & ICCPR & OP 1 & CAT & Art. 22 \\
\hline $\begin{array}{l}\text { Effect of Ratification } \\
\text { (Clustered standard error) }\end{array}$ & $\begin{array}{c}-.49 \\
(1.66)\end{array}$ & $\begin{array}{l}-.75 \\
(1.18)\end{array}$ & $\begin{array}{l}.38 \\
(.75)\end{array}$ & $\begin{array}{l}-.14 \\
(.41)\end{array}$ \\
\hline $\mathrm{N}$ ratification episodes & 22 & 22 & 36 & 10 \\
\hline $\mathrm{N}$ non-ratification episodes & 172 & 441 & 389 & 658 \\
\hline R-squared & 0.66 & 0.60 & 0.46 & 0.57 \\
\hline Matching & Yes & Yes & Yes & Yes \\
\hline Controls & \multicolumn{4}{|c|}{$\begin{array}{l}\text { Past FDI, physical integrity rights, political rights, Democracy, log GDP } \\
\text { p.c., log GDP p.c. }{ }^{2} \text {, GDP growth, regime durability, exchange rate } \\
\text { variability, inflation, and logged trade flows. The models include one- } \\
\text { through five-year lags of each of the time-varying variables. }\end{array}$} \\
\hline
\end{tabular}

Table 3: Linear regression of FDI inflows (per GDP) on treaty ratification with standard errors clustered by country and country random effects. The unit of observation is the (non-)ratification episode, with ratification occurring in year $t$, the covariates measured in the years $t-1, t-2, t-3, t-4$, and $t-5$. The outcome variable is total inflows of FDI as a fraction of GDP in years $t$ through $t+5$.

Bringing these models together, we find virtually no evidence to support the continued assertion in the literature and popular press that human rights treaty ratification is primarily the result of tangible sticks and carrots from states that support global adoption of human rights commitments. If tangible rewards exist, they do not seem to be operating through the channels posited as most likely by rewards theorists - aid, trade, and FDI. If, as we expect, tangible rewards do not exist, then rewards theory is in the difficult position of arguing that leaders of states routinely over-estimate the rewards that they will receive for ratifying human rights treaties.

\section{Intangible Rewards}

We now turn to the evidence for and against the widespread use of intangible benefits such as praise, acceptance, and reduced criticism to encourage ratification. We find some evidence of intangible benefits in the form of direct statements by the European Union praising the accession of states into human rights treaties. For example, a 2005 EU press release on the occasion of the eighth United Nations International Day in Support of Victims of Torture, mentions that the 
EU welcomes the ratification of UNCAT during the course of the last year by Liberia, Mauritania and the Syrian Arab Republic; and the ratification of OPCAT by Argentina, Croatia, Liberia, Mali and Mexico. ${ }^{11}$

Similar statements were made on the anniversary of this event in 2007 and 2009, recognizing in total three CAT ratifications and twenty-one ratifications of the Optional Protocol to the CAT in similar summary fashion.

A very small number of countries receive more individualized and specific praise. On February 16, 2009, the EU issued a press release which states:

The EU welcomes Azerbaijan's ratification of the Optional Protocol to the UN Convention against Torture...on 28 January 2009. The EU encourages Azerbaijan to take early steps towards implementing its obligations under the Optional Protocol by establishing a National Preventative Mechanism and cooperating with the Subcommittee on Prevention. ${ }^{12}$

To explore the prevalence of similar statements, we searched the 34,335 press releases to identify all examples of praise - defined as a statement displaying positive sentiment by the EU in specific reference to the ratification, accession, or implementation of an international human rights agreement (not limited to the four we focus on) by a specific country. ${ }^{13}$ In total, we found just eleven examples of praisefor-ratification in which the EU spent an entire press release praising ratification by a particular state and five additional cases of praise in which ratifications were noted in serial fashion as part of a larger press release. $^{14}$

11

http://europa.eu/rapid/pressReleasesAction.do?reference=PESC/05/62\&format=HTML\&aged=1\&language=EN\&gu iLanguage=en Brief number: 2005-0062PESC

12 "Declaration by the Presidency on behalf of the European Union on the ratification of the OPCAT by Azerbaijan," http://europa.eu/rapid/pressReleasesAction.do?reference=PESC/09/21\&format=HTML\&aged=1\&language=EN\&gu iLanguage $=$ en $\quad$ Brief number: 2009-0021PESC

${ }^{13}$ We first identified instances of praise by searching for the names of specific human rights agreements using the search function on the EU website. We then used these briefings to train a naïve Bayes text classifier to identify further examples of praise. From these results, we hand-coded the top 100 candidate texts and used the new list of positive examples of praise to retrain a new classifier to get a refined list of candidate texts. After three iterations, we had identified all of the examples of praise in the corpus.

${ }^{14}$ We found additional examples of praise that did not meet our definition of praise-for-ratification, including praise for countries that abolished the death penalty (but without reference to the OPCAT), or recognition of countries that improved their human rights practices in some way (but without reference to a specific agreement). 
Notably, although we did not specifically look for cases of criticism, we found many during our manual coding of the EU briefings. While we found 16 briefings that contained examples of praise for accession to human rights agreements, we found 31 briefings that criticized states specifically for violating the terms of their international commitments to human rights agreements. For example, a 2009 briefing stated that

The European Union condemns the recent executions by stoning in Al Shabab-controlled areas of Somalia, including of a woman accused of adultery... The European Union also calls on all relevant parties to ensure that the practice of execution by stoning is effectively and permanently terminated in the country, in conformity with the International Covenant on Civil and Political Rights, as well as the Convention against Torture...both of which Somalia has acceded to.

An entire subgroup of briefings is dedicated to condemning Iran's enforcement of the death penalty for crimes by minors in contravention of several of its international legal commitments:

The EU notes that these executions would be a direct contravention of the Islamic Republic of Iran's international commitments, specifically the International Covenant on Civil and Political Rights and the Convention on the Rights of the Child, both clearly prohibiting the execution of minors or people who have been convicted of crimes committed when they were minors.

We draw several conclusions from this analysis. First, praise for ratification exists in the official communications of the European Union and this praise might offer a plausible explanation for specific instances of treaty ratification. However, praise-for-ratification cannot be a general solution to the puzzle of human rights treaty ratification in part because large waves of ratification precede any significant evidence of praise by Europe. In fact, incidents of specific praise seem to be a recent phenomenon with only two examples in the 1990's, three examples from 2000-2008, and six examples in 2009 and 2010. It also seems that ratification can become a two-edge sword: when the EU criticizes the human rights practices of particular states, it never fails to mention instances where these rights violations are in contravention of the offending states legal obligations to human rights agreements.

To broaden the analysis, we considered whether the EU press releases contained evidence of more subtle praise for ratification in the form of increased positive sentiment toward ratifying countries. We measure the context in which ratifying countries are mentioned by identifying the ten words 
immediately surrounding each direct reference to a specific country by proper name during the years immediately preceding and following ratification. We then compare these words to a dictionary of term sentiments that codes whether 8,221 terms evoke something positive, negative, neutral, or both (Wilson, Wiebe, and Hoffmann 2005). If ratifying countries are subtly praised, we might expect countries to be mentioned in contexts with more positive connotations in the year following ratification. We find no evidence that this is the case for any of the four treaties we examine. Countries that ratify an agreement experience about the same levels of positive and negative affect before and after ratification.

Finally, we considered whether the EU press releases provide evidence that ratifying states are more accepted into the community of "modern" states by testing whether they enjoy more diplomatic visits in the year following ratification relative to the year prior. We looked for uses of the word "visit" in the ten words surrounding a specific mention of the proper name of a particular country. ${ }^{15}$ We then tested whether countries were more likely to receive visits in the year following ratification and find that they are not. For each of the four treaties we consider, the point estimate indicates a positive change in visits an average increase of between 0.1 and 0.3 visits depending on the treaty - but this difference is not significant at the 95 percent level for any of the four treaties. The difference does reach significance at the 90 percent level for the 50 countries that ratified Article 22 of the Convention against torture, perhaps indicating weak support for the rewards hypothesis.

Although we think praise-for-ratification is most likely to come from the European Union, we also test whether the US praises countries that ratify human rights agreements. Examining the 3,625 daily press briefings given by the Department of State between January 2, 1991 and December 23, 2008, we find that the US seems to completely ignore ratification of human rights agreements in its public statements. After struggling to find any praise using automated methods, we individually read each of the 151 briefings that mention a specific country in the two-week period surrounding its ratification of one of

\footnotetext{
${ }^{15}$ This method is crude but reasonably accurate: virtually all discussions of an official visit use the word "visit" in the context of the name of the visited country. To test whether "visit" could refer to actions besides official visits, we randomly sampled and coded 100 instances of the word "visit" and found that 95 percent of instances referred to some sort of official visit, suggesting that our measure is a reasonable proxy for the number of official visits to a particular country from the EU members.
} 
the four treaties in our study. The results are stark - none of the 151 briefings that mention countries in the two weeks surrounding ratification make any explicit mention of treaty ratification. The only implicit acknowledgment of a treaty ratification is a negative reference to "the Cuban Government...attempting to project an image of greater openness and willingness to cooperate with the international community on human rights" while simultaneously cracking down on human rights activists. ${ }^{16}$ Ratification of the CAT six days earlier is merely hinted at as part of Cuba's attempt to rehabilitate its "image" on human rights issues, and this attempt is met with criticism from the US rather than praise.

This lack of praise is striking because the US liberally praises and criticizes the actions and statements of foreign countries in its press briefings. For example, a briefing on March 11, 2002 approves of Mexican efforts to stop drug trafficking, but Mexican accession to the ICCPR Optional Protocol 1 just four days later goes unnoticed. A briefing on March 1, 2006 praises Indonesia as "world's third largest democracy," with "an active program of cooperation in counterterrorism, in democratic development, [and] in regional security," but fails to mention that Indonesia also acceded to the ICCPR only seven days before. The silence on treaty ratification is not even attributable to the unwillingness of the State Department to mention international law. On the $24^{\text {th }}$ of July, 1991, the State Department briefing mentions in that Venezuela is party to "the 1988 U.N. convention against drug trafficking," in connection with a discussion of narcotics trafficking in Latin America, but subsequent briefings fail to mention that just five days later, Venezuela acceded to the CAT.

As with the European Union, we also tested whether countries that ratified human rights agreements were discussed in more positive terms or received more diplomatic visits in the year following their ratification and found that there were no significant differences before and after ratification.

Finally, we turn to the possibility that countries ratify to reduce criticism from non-state actors such as human rights NGOs. To test this, we use data from Ron et al (2005) coding the number of news releases and background reports issued by Amnesty International criticizing a country's human rights

16 State Department Daily Press Briefing, May 23, 2009. Accessed 2009. 
performance. We adopt the negative binomial model used by Ron et al (2005) with the addition of two indicators for ratification of a treaty in the current year or the previous year. As with tangible rewards, we test for praise of each treaty separately although the results remain the same if we include indicators for all four treaties in the same model. Table 4 shows the regression results with the coefficients for the control variables omitted. We find no evidence that treaty ratification mutes criticism from Amnesty International. All of the coefficients are small and statistically insignificant at conventional levels and many of them are positive, suggesting that ratification does not reduce criticism.

\begin{tabular}{|c|c|c|c|c|}
\hline \multirow[t]{2}{*}{ Outcome Variable } & \multicolumn{4}{|c|}{ Combined AI news releases and background reports } \\
\hline & Model 1 & Model 2 & Model 3 & Model 4 \\
\hline Treaty & ICCPR & OP 1 & CAT & Art. 22 \\
\hline Ratification & $\begin{array}{c}0.022 \\
(0.10)\end{array}$ & $\begin{array}{l}-0.18 \\
(0.13)\end{array}$ & $\begin{array}{c}0.11 \\
(0.08)\end{array}$ & $\begin{array}{c}0.098 \\
(0.13)\end{array}$ \\
\hline Ratification $_{\mathrm{t}-1}$ & $\begin{array}{l}-0.008 \\
(0.10)\end{array}$ & $\begin{array}{l}-0.065 \\
(0.12)\end{array}$ & $\begin{array}{c}0.033 \\
(0.076)\end{array}$ & $\begin{array}{c}0.19 \\
(0.12)\end{array}$ \\
\hline $\mathrm{N}$ & 1,828 & 1,828 & 1,828 & 1,828 \\
\hline $\mathrm{N}$ of countries & 150 & 150 & 150 & 150 \\
\hline Random effects? & Yes & Yes & Yes & Yes \\
\hline Controls & \multicolumn{4}{|c|}{$\begin{array}{l}\text { Political terror scale, Polity IV scores, presence of armed conflict, percent } \\
\text { of population directly killed in armed conflict, GDP, military personnel, } \\
\text { population, US military aid, foreign aid (ODA), and average media } \\
\text { coverage. See Ron et al (CITE) for details. }\end{array}$} \\
\hline
\end{tabular}

Table 4: Negative binomial regression of the number of Amnesty International news releases on background reports, regressed on treaty ratification and a set of controls with country random effects.

\section{Conclusion: Domestic Politics as an Alternative Lens for Understanding Ratification}

The legal regime for international human rights has been one of the three main pillars of international order of the past half century. Alongside the Security Council dedicated to peace and security and the GATT/WTO dedicated to trade liberalization, the complex of international human rights treaties has been a central institution of the post-World War II order, and has become even more crucial in 
the post-cold war period (Simmons 2009). It is beyond the scope of this paper fully to address how and why this order was constructed. Rather, what we have tried to elucidate is that the politics of joining some of the most important agreements in this regime has been misunderstood. The notion that states have been induced to join such normatively important pacts as the ICCPR and the CAT hoping to receive external rewards from a core of wealthy, democratic countries simply does not bear empirical scrutiny. Our findings do not lend substantial support to claims that states ratify human rights treaties in hopes of attracting tangible rewards in the form of international aid, trade, and foreign direct investment, or intangible rewards such as praise and acceptance into the club of "responsible" countries. At best, we find minimal evidence of aid rewards from European states for ratification of several agreements, but these rewards hardly scale up to aggregate increases in aid. Furthermore, qualitative inquiries suggest that treaty ratification is unrelated to European aid policies and programs. We find that in general trade and FDI are unresponsive to treaty ratification and in some cases, ratification is followed by decreased trade.

Even more importantly, there is precious little evidence that states receive intangible rewards for human rights treaty ratification. Evidence of praise from the EU is extremely weak at best, while the US State Department utterly ignores treaty ratification in its public statements. This might not surprise those who view the United States as largely aloof from the international legal regime for human rights (Ignatieff 2005), but it is in stark contrast to theories of ratification that emphasize social "acceptance" as the major driver for treaty participation. Not even the major human rights non-governmental organization, Amnesty International, has much positive to say when states ratify human rights treaties. The idea that acceptance into a circle of modern statehood can explain ratification is not even supported by an uptick in state visits, which is one of the most important visible displays of peer acceptance.

These null findings are of significant theoretical importance. For states outside of the European and North American "core," participation in the global human rights regime has been portrayed as largely externally induced. This may be the natural result of a research agenda that has been propelled largely by scholars from "core" countries, or it may be the default setting given a general lack of research and knowledge about how non-western countries think about international law. In any case, given these 
findings, we believe that approaches focusing on domestic politics will be far more fruitful for understanding motives behind treaty ratification. It is beyond the scope of this paper to develop and present a full theory of treaty ratification, but we would point to several approaches that we think deserve more careful empirical attention. Moravscik, for example, has pioneered one of the most compelling arguments for states to ratify treaties, especially European conventions with teeth: they are actually useful in domestic politics to help sustain democratic momentum and lock in fairly recent rights gains (Moravcsik 2000). While broader support for the lock-in thesis is not especially strong (Cole 2005; Hawkins and Goodliffe 2006), we do think that the explanation for why governments commit to international human rights treaties is likely to be domestic rather than foreign. The "spiral model" developed by constructivists Risse, Ropp and Sikkink (1999) conceives of ratification as a tactical concession to rights proponents at both the domestic and international levels. Simmons found some evidence that governments in autocratic states have tended to ratify the ICCPR late in their office-holding, which seems to imply short term domestic reasons to ratify, as Pinochet's ratification of the CAT within months of the first democratic election of his tenure suggests (Simmons 2009). Some rationalists such as Vreeland (2008) argue that governments sometimes see ratification as a small concession to their domestic political opponents, while others such as Hollyer and Rosendorff (2011) think treaty ratification is a signal to domestic opponents that officials are willing to torture, despite such commitments. We think much more purchase on the politics of human rights treaty ratification will be realized by looking at the strategies and tactics governments employ domestically to keep a grip on their rule.

It is also important to acknowledge that not all external motivations for committing to human rights treaties are reward-seeking. Clearly a good number of states ratify human rights treaties because they want to set a positive example for others. This is routinely the explanation offered for some of the rights leaders (Landman 2005; Simmons 2009); it is even the argument heard within the United States among treaty proponents who do not prevail (Halberstam 1999). Without losing a critical perspective, a little less cynicism might serve in uncovering motives states have to commit to international human rights standards in a public and unequivocal fashion. We have only scratched the surface, but so far the 
evidence that states ratify human rights agreements for external rewards - tangible or intangible - appears weak indeed. 
References:

Alston, Philip, and James Crawford. 2000. The future of UN human rights treaty monitoring. Cambridge ; New York: Cambridge University Press.

Berkovitch, Nitza. 1999. From motherhood to citizenship : women's rights and international organizations. Baltimore: Johns Hopkins University Press.

Blanton, Shannon Lindsey, and Robert G Blanton. 2007. What Attracts Foreign Investors? An Examination of Human Rights and Foreign Direct investment. Journal of Politics 69 (1): 143-155.

Boli, John, and George M Thomas, eds. 1999. Constructing World Culture: Internationl Nongovernmental Organizations Since 1975. Stanford: Stanford University Press.

Boockmann, Bernhard. 2001. The ratification of ILO conventions: A hazard rate analysis. Economics \& Politics 13 (3): 281.

Carey, Sabine C. 2007. European Aid: Human Rights Versus Bureaucratic Inertia? Journal of Peace Research 44 (4): 447-464.

Chayes, Abram, and Antonia Handler Chayes. 1993. On compliance. International Organization 47 (2): 175-205.

Cingranelli, David L, and David L Richards. 2008. "The Cingranelli-Richards (CIRI) Human Rights Dataset." In. http://ciri.binghamton.edu/. January 27, 2009.

Clark, Ann Marie. 2001. Diplomacy of conscience : Amnesty International and changing human rights norms. Princeton: Princeton University Press.

Cole, Wade M. 2005. Sovereignty Relinquished? Explaining Commitment to the International Human Rights Covenants, 1966-1999. American Sociological Review 70 (3): 472-96.

Engleheart, Neil. 2003. "The Consequences of a Constructed Universal: Democracy and Civil Rights in the Modern State." In Constructing human rights in the age of globalization: International relations in a constructed world, eds. Mahmood Monshipouri, Neil Engleheart and Andrew J. Nathan. Armonk, N.Y.: M.E. Sharpe. 34-35.

Farber, Daniel A. 2002. Rights as signals. Journal of Legal Studies 31 (1): (Part 1) 83-98.

Goldsmith, Jack, and Eric A Posner. 2000. Understanding the Resemblance between Modern and Traditional Customary International Law. Virginia Journal of International Law 40: 639-

Goldstein, Judith L, Douglas Rivers, and Michael Tomz. 2007. Institutions in International Relations: Understanding the Effects of the GATT and the WTO on World Trade. International Organization 61 (1): 37-67.

Goodman, Ryan, and Derek Jinks. 2003. Measuring the Effects of Human Rights Treaties. European Journal of International Law 13: 171-183.

Guzman, Andrew T. 2002. International Law: A Compliance Based Theory. California Law Review 90: 1823.

Hafner-Burton, Emilie M, and Kiyoteru Tsutsui. 2005. Human Rights in a Globalizing World: The Paradox of Empty Promises. American Journal of Sociology 110 (5): 1373-1411.

- 2007. Justice Lost! The Failure of International Human Rights Law to Matter where Needed Most. Journal of Peace Research 44 (4): 407-425.

Hafner-Burton, Emilie M, Kiyoteru Tsutsui, and John W Meyer. 2008. International Human Rights Law and the Politics of Legitimation: Repressive States and Human Rights Treaties. International Sociology 23 (1): 115-141.

Halberstam, Malvina. 1999. "U.S. Ratification of the Convention on the Elimination of All Forms of Discrimination Against Women." In Women and international human rights 
law, eds. Kelly Dawn Askin and Dorean M. Koenig. Ardsley, N.Y.: Transnational. 141163.

Hastie, Trevor, Robert Tibshirani, and J. H. Friedman. 2009. The elements of statistical learning : data mining, inference, and prediction. 2nd ed of Springer series in statistics, . New York, NY: Springer.

Hathaway, Oona. 2002. Do Human Rights Treaties Make a Difference? Yale Law Journal 111 (8): 1935-2042.

. 2004. "The Promise and Limits of the International Law of Torture." In Torture : a collection, eds. Sanford Levinson and Alan M. Dershowitz. Oxford ; New York: Oxford University Press. 199-212.

- 2007. Why do Countries Commit to Human Rights Treaties? Journal of Conflict Resolution 51 (4): 588-621.

Hawkins, Darren. 2004. Explaining Costly International Institutions: Persuasion and Enforceable Human Rights Norms. International Studies Quarterly 48 (4): 779-804.

Hawkins, Darren, and Jay Goodliffe. 2006. Explaining Commitment: States and the Convention against Torture. Journal of Politics 68 (2): 358-71.

Ho, Daniel, Kosuke Imai, Gary King, and Elizabeth Stuart. 2007. Matching as Nonparametric Preprocessing for Reducing Model Dependence in Parametric Causal Inference. Political Analysis 15: 199-236.

Hollyer, James R, and B. Peter Rosendorff. 2011. Why Do Authoritarian Regimes Sign the Convention Against Torture? Signaling, Domestic Politics, and Non-Compliance. Quarterly Journal of Political Science 6: 275-327.

Ignatieff, Michael. 2001. "Human Rights as Politics." In Human rights as politics and idolatry, eds. Michael Ignatieff and Amy Gutmann. Princeton, N.J.: Princeton University Press. 352.

— ed. 2005. American exceptionalism and human rights. Princeton, N.J.: Princeton University Press.

Jensen, Nathan M. 2003. Democratic Governance and Multinational Corporations: Political Regimes and Inflows of Foreign Direct Investment. International Organization 57 (3): 587-616.

Kelley, Judith Green. 2004. Ethnic politics in Europe : the power of norms and incentives. Princeton, N.J.: Princeton University Press.

Krasner, Stephen D. 1999. Sovereignty : organized hypocrisy. of Princeton paperbacks. Princeton, N.J.: Princeton University Press.

Krasner, Stephen D., and Daniel Frotas. 1998. "Minority Rights and the Westphalian Model." In The international spread of ethnic conflict : fear, diffusion, and escalation, eds. David A. Lake and Donald S. Rothchild. Princeton, NJ: Princeton University Press. xiv, 392.

Landman, Todd. 2005. Protecting human rights : a comparative study. of Advancing human rights. Washington, D.C.: Georgetown University Press.

Li, Quan, and Adam Resnick. 2003. Reversal of Fortunes: Democratic Institutions and Foreign Direct Investment Inflows to Developing Countries. International Organization 57 (1): 175-211.

Lutz, Ellen, and Kathryn Sikkink. 2000. International human rights law and practice in Latin America. International Organization 54 (3): 633-659.

Meyer, John W., John Boli, George M. Thomas, and Francisco O. Ramirez. 1997. World society and the nation-state. American Journal of Sociology 103 (1): 144-181. 
Moberg, Andreas. 2009. "Villkorsklausuler - om avtalsklauser som utrikespolitiskt instrument." Uppsala.

Moravcsik, Andrew. 2000. The origins of human rights regimes: Democratic delegation in postwar Europe. International Organization 54 (2): 217-252.

Nielsen, Richard. 2008. "Foreign Aid for Human Rights." In. Cambridge MA: Harvard University.

Oberdörster, Uta 2008. Why Ratify? Lessons from Treaty Ratification Campaigns. Vanderbilt Law Review 61 (2): 681-.

OECD. 2008. International Development Statistics on CD-ROM. CD-ROM.

Posner, Eric A. 2008. Human Welfare, Not Human Rights. Columbia Law Review 108: 1758.

Risse, Thomas, Steve C. Ropp, and Kathryn Sikkink. 1999. The power of human rights : international norms and domestic change. of Cambridge studies in international relations ; 66. Cambridge, UK ; New York: Cambridge University Press.

Risse, Thomas, and Kathryn Sikkink. 1999. "The socialization of international human rights norms into domestic practice: introduction." In The power of human rights : international norms and domestic change, eds. Thomas Risse, Steve C. Ropp and Kathryn Sikkink. Cambridge, UK ; New York: Cambridge University Press. 1-38.

Ron, James, Howard Ramos, and Kathleen Rodgers. 2005. Transnational Information Politics: NGO Human Rights Reporting, 1986-2000. International Studies Quarterly 49 (3): 557588.

Sanahuja, Jose Antonio. 2000. Trade, politics, and democratization: The 1997 global agreement between the European Union and Mexico. Journal of Interamerican Studies and World Affairs 42 (2): 35-62.

Simmons, Beth A. 2009. Mobilizing for human rights : international law in domestic politics. Cambridge ; New York: Cambridge University Press.

Simmons, Beth A, and Daniel J Hopkins. 2005. The Constraining Power of International Treaties: Theory and Methods. American Political Science Review 99 (4): 623-631.

Smith, Heather M. forthcoming. Insincere Commitments: Human Rights Treaties, Abusive States and Citizen Activism. Georgetown University Press.

Trachtman, Joel P. forthcoming 2012. Who Cares About International Human Rights? The Supply and Demand of International Human Rights Law. Journal of International Law and Politics 45 (1).

Vreeland, James Raymond. 2008. Political Institutions and Human Rights: Why Dictatorships enter into the United Nations Convention Against Torture. International Organization 62 (1): 65-101.

Wilson, Theresa, Janyce Wiebe, and Paul Hoffmann. 2005. Recognizing Contextual Polarity in Phrase-Level Sentiment Analysis. Proceedings of HLT/EMNLP 2005, Vancouver, Canada.

Wotipka, Christine Min, and Francisco O. Ramirez. 2008. "World Society and Human Rights: An Event History Analysis of the Convention on the Elimination of all forms of Discrimination Against Women." In The Global Diffusion of Markets and Democracy, eds. Beth A Simmons, Frank Dobbin and Geoffrey Garrett. New York: Cambridge University Press. 303-343. 